manship swears that John fired him four times in one year. But John would always repent on sober second thought, and my colleague is still here. The fact is that beneath the occasionally gruff exterior was a shy and sensitive man actuated by serious and reflective moral passions. He was also a generous friend, husband, and father who could be an uproariously funny raconteur whose best stories were on himself. All of us who were fortunate enough to penetrate the imposing facade will remember him with great warmth and affection.

$\mathrm{He}$ is survived by his lovely and loyal wife Sally, with whom he recently celebrated their golden anniversary, and by three children, four grandchildren, and two great grandchildren.

Thomas A. Spragens, Jr. Duke University

\section{Thomas Page}

Thomas Page died September 4, 1991, in Urbana, Illinois. He graduated from the University of Kansas with a major in economics in 1934. He earned both a master's degree in public administration in 1948 and a doctorate in political science in 1951 from the University of Minnesota.

Professor Page married Barbara Kester at Lawrence, Kansas in 1937. She survives.

After graduating from the University of Kansas, Page worked for the National Bank of Topeka from 1934 through 1941; during the first eight months of World War II, he served as a labor market economist for the U.S. Employment Service for Kansas. In mid-1942, Page volunteered for the Army Air Corps combat glider pilot training program and served as glider instructor until his return to reserve status in November 1945 as a second lieutenant.

Following retirement from active military duty, Page embarked upon an academic career. He was an instructor in political science and research associate in the Bureau of Government Research at the University of Kansas from 1946 to 1948 and an instructor again from 1949 to 1951. In 1951 he accepted a joint appointment in the Department of Political Science and the Institute of Government and Public Affairs at the University of Illinois, UrbanaChampaign. Page was appointed Director, Masters Degree Program in Public Administration, Department of Political Science, University of Illinois, from 1966 until his retirement in 1974. Page was the author of monographs and articles on Kansas politics and Illinois government.

Page was also active in government service. He was a member of the Advisory Board to the Illinois Department of Personnel, 1961-79, and served as a member of the Urbana Civil Service Commission from 1974 until his death. In 1974, the Central Illinois Chapter of the American Society for Public Administration granted him its outstanding achievement award.

A noted pilot in high performance sailplanes, Page was elected to the Soaring Hall of Fame in 1975. He was the faculty sponsor of the Illinois glider club. After retiring from active soaring, he joined the Red Herring Fiction Workshop at the Channing-Murray Foundation, Urbana.

Samuel K. Gove

University of Illinois

\section{Leon H. Weaver}

Leon $\mathrm{H}$. Weaver, a founding member of the Section on Representation and Electoral Systems of the American Political Science Association, died on September 6, 1991, after an illness of several months. An emeritus professor at Michigan State
University, where he joined the faculty in 1960, he was active in the Section until shortly before his death, and he was chairman of the 1991 Section Nominating Committee.

Recipient of a B.S. (1936), M.A. (1938), and Ph.D. (1942) from the University of Illinois, Weaver taught at George Washington University and had a distinguished career in the federal government prior to joining the faculty of Michigan State University. He was an Emergency Planning Consultant with the Office of Civil and Defense Mobilization, Chief of Instruction at the National Civil Defense Training Center, Assistant Secretary of the National Security Resources Board, Secretary to the Policy Committee of the Department of State, and Adviser to the President's Commission on the Administration of Criminal Justice.

His publications include Law and Order Police Training for Civil Defense Emergency, The Civil Defense Debate, Nonpartisan Elections in Local Government, School Consolidation and State Aid in Illinois, and articles in journals and anthologies.

Weaver had a long-standing interest in the fairness of electoral systems and was an observer of elections in other nations. In addition to his own research, he urged others to conduct research on various electoral systems throughout the United States. He was particularly helpful to young scholars by encouraging their research interests. Leon Weaver's wise counsel and assistance will be missed by all who had the good fortune to know him and particularly by those who had the opportunity to work closely with him.

Joseph F. Zimmerman State University of New York at Albany

Bernard N. Grofman University of California, Irvine 